\title{
Estimated Policy Effects on Vietnam's Exports to Its Major APEC Trade Partners: A Gravity Model Approach
}

\author{
ERIC IKSOON IM \\ University of Hawaii-Hilo, Hawaii, USA \\ Email: eim@hawaii.edu \\ TAM BANG VU \\ University of Hawaii-Hilo, Hawaii, USA \\ Email: tamv@ hawaii.edu
}

\section{ARTICLE INFO}

Received:

May 29, 2013

Received in revised form

June 4, 2013

Accepted:

June 15, 2013

Keywords:

economic integration

trade liberalization

exchange rate

anti-corruption activity

\section{ABSTRACT}

This paper carries out an empirical assessment of the effects of a set of policy determinants of Vietnam's exports to its five major Asia Pacific trade partners (China, Japan, South Korea, Singapore, and US) over 23 years from 1989 to 2011 . In doing so, a gravity model is employed, which includes two sets of variables: one for gravity variables, and the other for policy-related variables. The latter includes four policy variables: real exchange rate, trade liberalization, anti-corruption activity, and WTO membership status. The effects of real exchange rate and anti-corruption activity are each specified as a linear function of the degree of trade liberalization to capture the indirect effects of trade liberalization on Vietnam's exports over time. The effect of trade liberalization on Vietnam's exports is specified as linear dependent on its WTO membership status to capture its direct effect and the additional effect attributable to Vietnam's accession to WTO on its exports. We find that Vietnam's trade liberalization has direct and indirect positive impacts on its trades, and its accession to WTO has a positive effect as well, contrary to some criticism otherwise. 


\section{INTRODUCTION}

Vietnam has enjoyed high export growth rates ever since its open-door policy was adopted in 1986. About two decades later in 2007, it joined the WTO, which was well received by Vietnamese enterprises looking for more favorable treatments from major trade partners in the Asia-Pacific region. The major purpose of joining WTO is to secure a strong international legal ground for protection against any unfair trade practices from other member countries. A study by Davis (2006) highlights such an example: Peru, a WTO member during 2000-2003 facing discriminatory policies from European WTO member countries against its scallops and sardines exports, filed a complaint with WTO, and was successful in having those policies withdrawn. That was not the case for Vietnam who was not a WTO member at that time. During 2002-2003, to be specific, Vietnam negotiated with the U.S. Government to maintain her catfish export quota to the U.S. within the framework of the Bilateral Trade Agreement, which was unsuccessful. This example demonstrates a clear difference between a member and a non-member of WTO.

However, Vietnam's high expectation about WTO was rather short-lived. Since its accession to the WTO, Vietnam has been struggling in shaking off the fierce competition from China in particular and others in general. In addition, it had to put up with a different set of new discriminatory measures taken by its important trade partners of the region in protecting their own enterprises. This raised the concern that Vietnam's economic growth might have been negatively affected by its accession to WTO. In fact, the annual growth rate of Vietnam's GDP fell $1.3 \%$ down to $6.5 \%$ in the five-year period (2007-2011) immediately following its accession to the WTO from an annual growth rate of $7.8 \%$ in the five-year period prior (2002-2006). Against this backdrop, there has been a conjecture that the accession to WTO did more harm than good to Vietnamese economy in particular and developing countries in general. However, so far there has been extended no empirical evidence that supports the conjecture.

In our study, there are four policy-oriented determinants of Vietnam's export to be considered: exchange rate, the trade liberalization, anti-corruption activity and Vietnam's WTO membership. In order to find effects of these four policy-oriented variables on the exports, we analyze Vietnam's exports to its leading APEC trading partners: China, Japan, South Korea, Singapore, and the US, using the gravity model for panel data. In doing so, four policy-related variables (the exchange rate, trade 
liberalization, anti-corruption activity, and Vietnam's accession to the WTO) are appropriately incorporated into the gravity equation, in addition to five gravity variables: per capita GDPs of exporting and importing countries, per capita investments of importing and exporting countries, and bilateral distance.

The more a country liberalizes its trade, the more likely the country's firms are to voluntarily cooperate and share their individual experiences with their counterparts of other countries, which may generate indirect positive effects in the process. Therefore, coefficients for exchange rate and anti-corruption activity in the gravity model are specified respectively as a linear function of trade liberalization so that we can capture their indirect as well as direct effects on export. This creates a built-in heteroskedasticity problem, so we adopt the generalized least squares (FGLS) method as a solution. A dummy variable $(W T O)$ is created to distinguish years prior to Vietnam's accession to the WTO from the rest in the sample period, along with the interaction term with trade liberalization.

Section 2 of this paper introduces the methodology and data issues. Section 3 analyzes the estimation results. Section 4 provides policy implications, and Section 5 is for conclusions.

\section{METHODOLOGY AND DATA}

\section{a. Methodology:}

Tinbergen (1962), Poyhonen (1963) and Linneman (1966) were the three earliest researchers who applied the gravity model in their empirical analyses of international trade flows without theoretical justification for its validity[1].

The idea of gravity model has its origin in Newton's law of gravitation in physics:

$$
f_{i j}=G \frac{m_{i} m_{j}}{d_{i j}^{2}}
$$

where $f_{i j}$ denotes the force between two objects with $m_{i}$ and $m_{j}$ denoting their respective masses, $d_{i j}$ the distance between them, and $G$ the gravitational constant.

Tinbergen (1962) adapted the gravity model in Equation (1) by specifying that the bilateral trade between two countries as measured by $x_{i j}$ (i.e. export from country $i$ to 
country $j$ ) is determined by their respective outputs ( $g d p_{i}$ and $\left.g d p_{j}\right)$ and the distance between the two countries $\left(d_{i j}\right)$ :

$$
x_{i j}=A_{i j}\left(g d p_{i}\right)^{\beta_{i}}\left(g d p_{j}\right)^{\beta_{j}} d_{i j}^{\beta_{d}} \quad\left(A_{i j}, \beta_{i}, \beta_{j}>0 ; \beta_{d}<0\right) .
$$

The stochastic version of Equation (2) for panel data, including the stochastic term, can be written as follows:

$$
x_{i j, t}=A_{i j, t}\left(g d p_{i, t}\right)^{\beta_{i}}\left(g d p_{j, t}\right)^{\beta_{j}} d_{i j}^{\beta_{d}} e^{w_{i j, t}}
$$

where

$$
\begin{aligned}
& w_{i j, t}=u_{i}+s_{t}+e_{i j, t} ; \\
& u_{i} \sim N\left(0, \sigma_{u}^{2}\right) ; \quad s_{t} \sim N\left(0, \sigma_{s}^{2}\right) ; \quad e_{i j t} \sim N\left(0, \sigma_{e}^{2}\right)
\end{aligned}
$$

Taking logarithm of Equation (3), we obtain a standard log-liner model suitable for the least-squares estimation:

$$
\begin{aligned}
\ln x_{i j} & =\ln A_{i j, t}+\beta_{x} \ln g d p_{i, t}+\beta_{m} \ln g d p_{j, t}+\beta_{d} \ln d_{i j}+w_{i j, t} \\
& \equiv A_{i j, t}^{*}+\left(\beta_{x} \ln g d p_{i, t}+\beta_{m} \ln g d p_{j, t}+\beta_{d} \ln d_{i j}\right)+w_{i j, t} \\
& \equiv A_{i j, t}^{*}+\xi_{i j, t}+w_{i j, t}
\end{aligned}
$$

To serve our purpose, we redefine the basic gravity model in Equation (4) as follows:

$$
x_{i j, t}=p c x_{i j, t}
$$$$
A_{i j, t}^{*}=\beta_{o}+\beta_{1} O P E N_{i, t}+\beta_{2} E X C_{i j, t}+\beta_{3} A C R_{i, t} ;
$$$$
\xi_{i j, t}=\beta_{41} \ln p c g d p_{i, t}+\beta_{42} \ln p c g d p_{j, t}+\beta_{43} \ln p c i n v_{i}+\beta_{44} \ln p c i n v_{j}+\beta_{45} \ln d i s t_{i j}
$$$$
=\left(\begin{array}{llllllll}
\ln p c g d p_{i, t} & \ln p c g d p_{j, t} & \ln p c i n v_{i, t} & \ln p c i n v_{j, t} & \operatorname{dist} t_{i j}
\end{array}\right)\left(\begin{array}{llllll}
\beta_{41} & \beta_{42} & \beta_{43} & \beta_{44} & \beta_{45}
\end{array}\right)^{\prime}
$$$$
\equiv \ln \left(\operatorname{pcgdp}_{i, t} \quad \operatorname{pcgdp}_{j, t} \quad \operatorname{pcinv}_{i, t} \quad \operatorname{pcinv}_{j, t} \quad \operatorname{dist}_{i j}\right)\left(\begin{array}{llllll}
\beta_{41} & \beta_{42} & \beta_{43} & \beta_{44} & \beta_{45}
\end{array}\right)^{\prime}
$$$$
\equiv \ln \zeta_{i j}\left(\begin{array}{lllll}
\beta_{41} & \beta_{42} & \beta_{43} & \beta_{44} & \beta_{45}
\end{array}\right)^{\prime} \equiv \ln \zeta_{i j, t} \beta_{4}
$$

in which

$p c x_{i j}=$ per capita export from country $i$ to country $j$ at $t$;

$O P E N_{i, t}=$ degree of trade liberalization of country $i$ at $t$; 
$E X C_{i j, t}=$ exchange rate (country $i$ 's currency in terms of country $j^{\prime} s$ ) at $t$; $A C R_{i, t}=$ country $i$ 's anti-corruption activity at $t$;

$\operatorname{pcgdp}_{i, t}=$ per capita gdp of country $i$ at $t$;

$\operatorname{pcgdp}_{\mathrm{j}, t}=$ per capita gdp of country $j$ at $t$;

$\operatorname{pcinv}_{\mathrm{i}, t}=$ per capita investment of country $i$ at $t$;

pcinv $v_{\mathrm{j}, t}=$ per capita investment of country $j$ at $t$.

Substituting Equation (5) into Equation (4) results in:

$\ln p c x_{i j, t}=\beta_{o}+\beta_{1} O P E N_{i, t}+\beta_{2} \ln E X C_{i j, t}+\beta_{3} A C R_{i, t}+\ln g_{i j, t} \beta_{4}+w_{i j, t}$

In Model (6), the three subscripts are defined as

$$
\begin{gathered}
i=\text { Vietnam } \\
j=\left\{\begin{array}{l}
1=\text { China } \\
2=\text { Japan } \\
3=\text { Korea } \\
4=\text { Singapore } \\
5=\mathrm{US}
\end{array}\right. \\
t=\left\{\begin{array}{c}
1=1989 \\
\vdots \\
23=2011
\end{array}\right.
\end{gathered}
$$

To capture the impact of trade liberalization $(O P E N)$ on the effects of exchange rate and anti-corruption activity on Vietnam's exports, we specify the coefficients of EXC and $A C R$ as:

$$
\begin{aligned}
& \beta_{2}=\beta_{21}+\beta_{22} \text { OPEN }_{i, t}+v_{i, t} \\
& \beta_{3}=\beta_{31}+\beta_{32} \text { OPEN }_{i, t}+z_{i, t}
\end{aligned}
$$

where 


$$
v_{i j, t} \sim N\left(0, \sigma_{u}^{2}\right) ; \quad z_{i j, t} \sim N\left(0, \sigma_{z}^{2}\right)
$$

Substituting extraneous equations in System (7) into Model (6) yields:

$\ln p c x_{i j, t}=\beta_{o}+\beta_{1} \ln O P E N_{i j, t}$

$$
\begin{aligned}
& +\left(\beta_{21}+\beta_{22} \text { OPEN }_{i, t}+v_{i j, t}\right) \ln E X C_{i j, t} \\
& +\left(\beta_{31}+\beta_{32} \text { OPEN }_{i, t}+z_{i j, t}\right) \ln A C R_{i, t}
\end{aligned}
$$$$
\ln \zeta_{i j, t} \theta+w_{i j, t}
$$

To capture the direct effect of Vietnam's trade liberalization on Vietnam's export and the indirect effect attributable to WTO membership status, we specify $\beta_{1}$ as

$$
\beta_{1}=\beta_{11}+\beta_{12} W T O_{i, t}
$$

where

$$
W_{i, t}=\left\{\begin{array}{l}
=0 \text { before accession } \text { to WTO } \\
=1 \text { otherwise }
\end{array}\right.
$$

so that $\beta_{11}$ captures the direct effect of trade liberalization on the export whereas $\beta_{12}$ captures the indirect effect.

Substituting Equation (9) into Equation (8) then leads us to the final form of gravity model for estimation:

$\ln p c x_{i j, t}=\beta_{o}+\beta_{11} \ln O P E N_{i, t}+\beta_{12}\left(\ln O P E N_{i, t} \times W T O_{i, t}\right)$

$+\beta_{21} \ln E X C_{i j, t}+\beta_{22}\left(O P E N_{i, t} \times \ln E X C_{i j, t}\right)+\beta_{31} A C R_{i, t}+\beta_{32}\left(O P E N_{i, t} \times \ln A C R_{i, t}\right)$

$+\ln \zeta_{i j, t} \theta+\mu_{i j, t}$

where

$$
\mu_{i j, t}=\left(v_{i j, t} \times \ln E X C_{i j, t}\right)+\left(z_{i j, t} \times \ln A C R_{i, t}\right)+w_{i j, t}
$$

which is heteroskedastic:

$$
\sigma_{\mu_{j, t}}^{2}=E\left(\mu_{i j, t}^{2}\right)=\sigma_{v}^{2}\left(\ln E X C_{i j, t}\right)^{2}+\sigma_{z}^{2}\left(A C R_{i, t}\right)^{2}+\sigma_{u}^{2}+\sigma_{s}^{2}+\sigma_{e}^{2} \neq \sigma^{2}
$$

For notational simplicity, we can rewrite Equation (10) in matrix form as 


$$
y=X \beta+\mu
$$

Then,

$$
E[\mu]=0, \quad \operatorname{Cov}[\mu]=E\left[\mu \mu^{\prime}\right]=Q \neq \sigma_{w}^{2} I_{115}
$$

where

$$
Q=\operatorname{Diag}\left[\sigma_{\mu_{i j, t}}^{2}\right] \quad(i=\text { Vietnam; } j=1,2,3,4,5 ; t=1,2, \ldots, 23)
$$

To adjust for the heteroskedasticity for estimation efficiency gain, we carry out a liner transformation on Equation (12) by pre-multiplying $P$ such as $P^{\prime} P=Q^{-1}$.

$$
y^{*}=X^{*} \beta+\mu^{*}
$$

where

$$
y^{*}=P y ; \quad X^{*}=P X ; \quad \mu_{115 \times 1}^{*}=\left(\mu_{i 1,1} / \sigma_{i 1,1}, \mu_{i 2,1} / \sigma_{i 2,1}, \ldots, \mu_{i 5,23} / \sigma_{i 5,23}\right)^{\prime}
$$

OLS estimator of $\beta$ in (13), or equivalently GLS estimator of $\beta$ in (12), is

$$
\hat{\beta}=\left(X^{\prime} \mathrm{Q}^{-1} X\right)^{-1} X^{\prime} \mathrm{Q}^{-1} y
$$

Since $Q$ is unknown, the second best choice in practice is the feasible GLS estimator (FGLS):

$$
\tilde{\beta}=\left(X^{\prime} \hat{\mathrm{Q}}^{-1} X\right)^{-1} X^{\prime} \hat{\mathrm{Q}}^{-1} y
$$

which is not the best linear unbiased but consistent estimator of $\beta$, and its asymptotic properties are the same as those of the GLS estimator.

\section{b. Data Issues:}

Data on bilateral trade are from the Direction of Trade Statistics CD (2009) provided by the IMF, updated with the data on IMF website. These data are for the period from 1989 to 2011 and in current US dollars. Data for per capita income, real GDP, population, and GDP deflator are from US Department of Agriculture website. We convert the bilateral trade data in current dollars to those in constant dollars using the GDP deflators. Data on education as a proxy for human capital and investment are from World Development Indicator (WDI) website. The aforementioned aggregate variables, except for per capita income, are then divided by population to obtain per capita measures. 
Since many East Asian countries, which followed export-led growth policy, were still considered closed economies by most economists because they refused to open their door to imports during 1980-1990, we use imports-GDP ratios instead of (imports + exports)-GDP ratios to proxy trade liberalization $(O P E N)$. Data on corruption are from the Worldwide Governance Indicators Series on World Bank website. Data on distance are from Institute for Research on the International Economy website. Data on real exchange rates are from the US Department of Agriculture. They are expressed as comparative exchange rate between a country and US real exchange rate, which is normalized to unity. We convert this dataset to bilateral exchange rate between Vietnam and each of its partners by forming the ratio of the two exchange rates.

\section{ESTIMATION RESULTS}

A Hausman Test performed for method selection indicates that a fixed effect (FE) estimation approach is more appropriate than a random effect one. Hence, both estimations are carried out by fixed effect FGLS (FEFGLS).

Table 1 below shows regression analysis of Vietnam's exports to its trade partners. We find that the exchange rate appreciation has a significant negative direct impact, as expected, on Vietnam's per capita exports, but we also find a significant indirect negative impact though smaller than the direct effect: one percent appreciation of EXC decreases Vietnam's per capita exports by $0.274 \%$ (direct effect) with an additional $0.092 \%$ for each unit of trade liberalization (indirect effect). In contrast, the anticorruption activity has a significantly positive direct effect on Vietnam's exports as well as positive indirect effect attributed to the anti-corruption activity, each statistically significant at 5\% level: one unit increase in anti-corruption activity increases the per capita export by $0.012 \%$ (direct effect) entailed by $0.075 \%$ times the degree of trade liberalization (indirect effect). Trade liberalization by itself has a positive effect of its own on Vietnam's exports: one percent increase in the imports/GDP ratio increases Vietnam's exports by $0.158 \%$ with an additional $0.037 \%$ since her accession to WTO in 2007. The combined effect is $0.195 \%$, which is significant at $1 \%$ level. 
Table 1: FEFGLS Estimation of Vietnam's Exports to Its Major APEC Trade Partners

Regressand: Logarithm of Bilateral Exports per Capita

\begin{tabular}{|c|c|c|c|}
\hline Regressors & $\begin{array}{c}\text { (1) } \\
\text { Direct Effect }\end{array}$ & $\begin{array}{c}\text { (2) } \\
\text { Indirect Effect }\end{array}$ & $\begin{array}{c}\text { (3) } \\
\text { Combined Effect }\end{array}$ \\
\hline $\ln O P E N$ & $\begin{array}{c}0.158^{+++} \\
(0.007)\end{array}$ & & \\
\hline $\operatorname{lnOPEN\times WTO}$ & & $\begin{array}{c}0.037^{++} \\
(0.018)\end{array}$ & \\
\hline $\ln O P E N+\ln O P E N \times W T O$ & & & $\begin{array}{c}0.195^{+++} \\
(0.009)\end{array}$ \\
\hline $\ln E X C$ & $\begin{array}{l}-0.274^{+++} \\
(0.008)\end{array}$ & & \\
\hline $\ln E X C \times O P E N$ & & $\begin{array}{c}-0.092^{++} \\
(0.039)\end{array}$ & \\
\hline $\ln E X C+\ln E X C \times O P E N$ & & & $\begin{array}{c}0.366^{++} \\
(0.032)\end{array}$ \\
\hline $\ln A C R$ & $\begin{array}{c}0.012^{++} \\
(0.035)\end{array}$ & & \\
\hline inACR $\times O P E N$ & & $\begin{array}{c}0.075^{+++} \\
(0.007)\end{array}$ & \\
\hline $\ln A C R+\operatorname{in} A C R \times O P E N$ & & & $\begin{array}{c}0.087^{++} \\
(0.048)\end{array}$ \\
\hline $\ln p c y_{i}$ & $\begin{array}{c}1.269^{++} \\
(.041)\end{array}$ & & \\
\hline $\ln p c y_{j}$ & $\begin{array}{l}0.754^{++} \\
(.031)\end{array}$ & & \\
\hline In pcinvi & $\begin{array}{l}0.012^{++} \\
(.023)\end{array}$ & & \\
\hline $\ln p \operatorname{cin} v_{j}$ & $\begin{array}{c}0.018^{++} \\
(0.045)\end{array}$ & & \\
\hline ln dist $_{i j}$ & $\begin{array}{c}-.0243^{++} \\
(.025)\end{array}$ & & \\
\hline Observations & 115 & & \\
\hline$p$-value for F-test & 0.000 & & \\
\hline$p$ - value for Hausman test & 0.029 & & \\
\hline Adjusted R & 0.824 & & \\
\hline$p$-value for Autocorrelation & 0.357 & & \\
\hline$p$-value for Heteroskedasticity & 0.436 & & \\
\hline
\end{tabular}

Notes: numbers within parentheses are $p$-values; ${ }^{+++},{ }^{++}$, and ${ }^{+}$signify statistical significances at 1,5 , and 10 percent levels, respectively. 
To test the sign robustness, we replace all the logarithmic variables in (8) with their differentials, which represent growth of respective variables, for re-estimation as follows:

$$
\begin{aligned}
& \Delta \ln p c x_{i, t}=\gamma_{o}+\gamma_{11} \Delta \ln O P E N_{i, t}+\gamma_{12}\left(\Delta \ln O P E N_{i, t} \times W T O_{i, t}\right)+\gamma_{21} \Delta \ln E X C_{i j, t} \\
& +\gamma_{22}\left(O P E N_{i, t} \times \Delta \ln E X C_{i j, t}\right)+\gamma_{31} \Delta \ln A C R_{i, t}+\gamma_{32}\left(O P E N_{i, t} \times \Delta \ln A C R_{i, t}\right)+\Delta \ln \zeta_{i j, t} \gamma_{4}+w_{i j, t}
\end{aligned}
$$

Table 2 below reports the estimation results for Equation (16). Once again, we see that the exchange rate appreciation has negative direct and indirect effects on Vietnam's export growth, each significant at 5\% level: one percent appreciation of EXC decreases the per capita export growth by $0.064 \%$ (direct effect) with additional $0.021 \%$ times trade liberalization (indirect effect). Also, the direct effect of anti-corruption activity is positive but small relative to the indirect effect, both significant at $5 \%$ level: one unit increase in the anti-corruption index number increases Vietnam's per capita export growth by $0.003 \%$ (direct effect) with additional $0.015 \%$ times trade liberalization (indirect effect). Finally, trade liberalization has a statistically significant positive effect on Vietnam's exports (direct effect) regardless of WTO membership status but with a statistically significant additional positive effect thanks to her accession to WTO (indirect effect), each significant at 5\% level: one unit increase in Vietnam's trade liberalization increases the per capita export growth by $0.054 \%$ with an additional $0.016 \%$ after. The statistically significant additional $0.016 \%$ is a clear evidence that Vietnam's accession to WTO in 2007 has boosted its exports, thereby contributing to its economic growth through the multiplier effect through the economy.

Table 2: FEFGLS Estimation of Vietnam's Exports to Its Major APEC Trade Partners

Regressand: Differential of Logarithm of Per Capita Bilateral Exports

\begin{tabular}{lccc}
\hline \multicolumn{1}{c}{ Regressors } & $\begin{array}{c}(\mathbf{1}) \\
\text { Direct Effect }\end{array}$ & $\begin{array}{c}(\mathbf{2}) \\
\text { Indirect Effect }\end{array}$ & $\begin{array}{c}\text { (3) } \\
\text { Combined Effect }\end{array}$ \\
\hline$\Delta \ln O P E N$ & $0.054^{++}$ & & \\
$\Delta \ln O P E N \times W T O$ & $(0.037)$ & $0.016^{++}$ & \\
$\Delta \ln O P E N+\triangle \ln O P E N \times W T O$ & & $(0.023)$ & $0.195^{++}$ \\
$\Delta \ln E X C$ & & & $(0.34)$ \\
$\Delta \ln E X C \times O P E N$ & $-0.064^{++}$ & &
\end{tabular}




\begin{tabular}{|c|c|c|c|}
\hline \multicolumn{3}{|l|}{$\Delta \ln E X C+\Delta \ln E X C \times O P E N$} & \multirow[t]{2}{*}{$\begin{array}{c}0.095^{++} \\
(0.029)\end{array}$} \\
\hline$\triangle \ln A C R$ & $\begin{array}{c}0.003^{++} \\
(0.014)\end{array}$ & & \\
\hline$\triangle \ln A C R \times O P E N$ & & $\begin{array}{c}0.015^{+++} \\
(0.004)\end{array}$ & \\
\hline$\triangle \ln A C R+\triangle \ln A C R \times O P E N$ & & & $\begin{array}{c}0.018^{++} \\
(0.008)\end{array}$ \\
\hline$\Delta{\ln p c y_{i}}$ & $\begin{array}{c}0.926^{+++} \\
(.004)\end{array}$ & & \\
\hline$\Delta{\ln p c y_{j}}$ & $\begin{array}{c}0.587^{++} \\
(.027)\end{array}$ & & \\
\hline$\Delta \operatorname{lnp} c v_{i}$ & $\begin{array}{c}0.014^{++} \\
(.042)\end{array}$ & & \\
\hline$\Delta p \operatorname{cin} v_{j}$ & $\begin{array}{c}0.019^{++} \\
(0.036)\end{array}$ & & \\
\hline$\Delta$ lndist $_{i j}$ & $\begin{array}{c}-.0248^{++} \\
(.026)\end{array}$ & & \\
\hline Observations & 110 & & \\
\hline$p$-value for F-test & 0.000 & & \\
\hline$p$ - value for Hausman test & 0.034 & & \\
\hline Adjusted R & 0.715 & & \\
\hline$p$-value for Autocorrelation & 0.634 & & \\
\hline$p$-value for Heteroskedasticity & 0.587 & & \\
\hline
\end{tabular}

Notes: numbers within parentheses are $p$-values; ${ }^{+++},{ }^{++}$, and ${ }^{+}$signify statistical significances at 1,5 , and 10 percent levels, respectively.

\section{POLICY IMPLICATIONS}

The estimation results discussed in the previous section show that the negative effect of exchange rate on Vietnam's exports increases with trade liberalization, contributing to the volatility of Vietnam's exports, and thereby destabilizing its economy through the multiplier effect. Therefore, it may be a risky proposition that Vietnam floats its currency as a concession to its developed trade partners in exchange for favorable. To wit, Vietnam may be better off by maintaining its current exchange rate policy - managed floating exchange rate - instead of conceding to otherwise pressures from its trade partners and following a freely floating exchange rate. With regard to the effect of the anti-corruption activity, it has direct positive effect on Vietnam's exports accompanied by an even greater indirect effect attributed to trade liberalization. This implies that it is desirable for Vietnamese central and local governments to step up their anti-corruption activity in step with furthering trade liberalization. 
Trade liberalization has a direct positive effect on Vietnam's exports not only before but after its accession to WTO in 2007. In addition, it has had some additional positive effect since 2007, which implies that the losses on becoming a WTO member country are more than offset by the benefits therefrom. The benefits may be well exemplified by Vietnam's success with a complaint filed to the WTO in February 2010 against US restriction on its shrimp import from Vietnam that was resolved successfully in favor $\mathrm{f}$ Vietnam in September 2011. Vietnam might want to initiate another legitimate case against US restriction on Vietnam's basa/catfish exports, which may be well successful if filed to WTO in the foreseeable future. Further potential benefits can be reaped by joining other trade blocks, the opportunities of which are available to WTO member countries. Ngo Thi Hai Xuan (2013) points out that by joining the Trans-Pacific Partnership (TPP), Vietnam will be able to have its trade partners lower their tariffs and tear down non-tariff barriers. Vietnamese firms need to improve their negotiation capacity through closer contacts with Vietnamese delegates in trade blocs and also through joint research activities to exchange views and share experiences with their counterparts in WTO and TPP member countries.

Our analysis does not extend an empirical support for the view that Vietnam's accession to WTO is accountable for its slow economic growth. The current global financial crisis in its early stage may have set the stage for Vietnam's slower economic growth. In this vein, Vietnam may need in its policy package a flexible monetary policy, measures for creating more favorable investment environment, and enhanced transparency to attract more foreign investment. It may be needed to have upgraded managerial skills to stave off further deterioration of the financial market. It would be an encouraging step forward if Vietnam's private sector sets a goal to raise its productivity to a higher level to effectively reduce stiff competition from their foreign counterparts instead of crying foul. Another equally important venue is to develop and introduce uniquely Vietnamese products. An optimal mix of diverse strategies will be certain to enhance the competitive edge of Vietnam's domestic firms vis-à-vis its foreign counterparts in both domestic and foreign markets.

\section{CONCLUSION}

Using data on bilateral trade of Vietnam with its major APEC trade partners, we estimated the effects of policy variables: foreign exchange rate, anti-corruption activity, trade liberalization, and WTO membership status on Vietnam's exports over time. The 
results indicate that exchange rate appreciation and anti-corruption activity, as expected, have their respective negative and positive effects. However, each effect is augmented by trade liberalization: the more the liberalization, the greater the effect of each variable. Moreover, trade liberalization itself has a positive direct effect on Vietnam's exports to its major APEC trade partners, with an additional positive effect from the year of its accession to WTO. Therefore, the conjecture to the effect that Vietnam's accession to WTO is the culprit of its subsequent slower economic growth is not supported by the outcome of our empirical analysis. The real culprit may have to be found elsewhere. This opens up opportunities for further research in this direction, which is beyond the scope of this study

\section{Note}

[1] Anderson (1979) first introduced an economic theoretical foundation for the gravity model in a very restrictive framework (see also Feenstra (2004) for an elaborate discussion).

\section{References}

Anderson, J. E. (1979), “A Theoretical Foundation for the Gravity Equation.” American Economic Review, 69 (1), 106-16.

Davis, C.L. (2006), "Do WTO Rules Create a Level Playing Field? Lessons from the Experience of Peru and Vietnam," Working Paper, Department of Politics, Princeton University, 1-43.

Direction of Trade Statistics CD (2009), International Monetary Funds, Database and Browser, Publications Services, Washington D.C.

Feenstra, R. C. (2004), Advanced International Trade: Theory and Evidence, Princeton University Press, New Jersey.

Linneman, H. (1966), An Econometric Study in International Trade Flows, North Holland, Amsterdam.

Ngo Thi Hai Xuan (2013), “The Trans-Pacific Partnership Agreement: Opportunities and Challenges to Vietnam's Apparel Exported to the US Market," Journal of Economic Development, April (216), 96-107.

Poyhonen, P. (1963), "A Tentative Model for the Volume of Trade between Countries," Weltwirtchaftliches Archiv, (90), 93-99.

Tinbergen, J. (1962), Shaping the World Economy: Suggestions for an International Economic Policy, The Twentieth Century Fund, New York. 